\title{
PENERAPAN APLIKASI SISTEM INFORMASI KEPENDUDUKAN BERBASIS WEB PADA KANTOR KEPALA DESA PUPUT KEC. SIMPANGKATIS
}

\author{
Sujono \\ Program Studi Sistem Informasi \\ STMIK Atma Luhur \\ Email: sujono@atmaluhur.ac.id
}

\begin{abstract}
ABSTRAK
Kantor Kepala Desa Puput merupakan salah satu Kantor Kepala Desa di Kecamatan Simpangkatis Kabupaten Bangka Tengah yang memiliki peran penting dalam perkembangan teknologi di lembaga pemerintahan. Perkembangan teknologi sistem informasi dengan penggunaan komputer dapat menghasilkan pengolahan data yang cepat, tepat dan akurat sehingga lebih efektif dan efisien. Sistem informasi kependudukan yang diperlukan seperti Formulir Permohonan KK, Surat Keterangan Kelahiran, Kematian, Pindah Jiwa, Pindah Datang dan Formulir E-KTP yang sangat diperlukan keakuratan dan ketelitian dalam pendataannya. Permasalahan yang sering terjadi di Kantor Kepala Desa Puput dikarenakan belum adanya sistem kependudukan sehingga pengolahan data kependudukannya masih secara manual yang akan memperlambat kinerja pada instansi tersebut. Media penyimpanan data kependudukannya pun masih menggunakan dokumen-dokumen sehingga rentan kehilangan atau kerusakan data. Sering terjadinya pengulangan data kependudukan dikarenakan tidak adanya pendataan yang telah tersistem. Berdasarkan permasalahan tersebut, dibuatlah sistem kependudukan berbasis web dengan tujuan agar dapat mempermudah pendataan dan pengolahan data penduduk pada Kantor Kepala Desa Puput serta mengurangi kesalahan dalam penyajian data dan mempermudah dalam menghasilkan laporan kependudukan. Untuk merancang dan menganalisa sistem manual sehingga menjadi sistem terkomputerisasi menggunakan metodologi Analisis berorientasi obyek(Object-Oriented Analisis). Dari analisa dan perancangan yang sudah disesuaikan dengan kebutuhan di Kantor Kepala Desa di Kecamatan Simpangkatis menghasilkan sebuah aplikasi berbasis web yang dapat mengatasi masalah yang ada.
\end{abstract}

Kata kunci: kependudukan,aplikasi, sistem informasi, berbasis web.

\begin{abstract}
Region office of Puput is an official office in Simpangkatis sub-district of Bangka Tengah which has main role as government technology development. Information system of technology development by using computer extremely creates data tabulating in a short time, accurate, effective and efficient. The information system of society is needed to discover some data collection such as identity card, family card, certificate of birth, death, moving, new comer, and form of electronic identity card, whereas need high accuracy and cautious. The problem of this study is the region office of Puput does dot has the technology system in tabulating data. Every single data collection tabulated manually by employee, it needs much time and accuracy. Moreover, data is saved by hard copies by much documents which can be lose and broken down somewhere. As the result, the employee have to do re-collecting the data and tabulate them in twice even for many times. The lack of capability in maintaining and developing the society system of information from this office caused suboptimal result in presenting the proposals and reports. By knowing the problems of the studies above, the researcher made the system of society information through web based. The objectives of the study are to ease and tabulate society data at this region office. It also tries to avoid human error in presenting the data and to make better proposals and reports. To design and analyze the manual system so that it becomes a computerized system using Object-Oriented Analisis method. From analysis and design that has been adapted to the needs in official office in Simpangkatis sub-district, it can solve existing problems.
\end{abstract}

Keywords: population, application, information system, web based.

\section{PENDAHULUAN}

Saat ini dunia telah mengenal suatu teknologi yang dinamakan internet. Dengan internet ini semua orang dapat berkomunikasi dengan orang lain yang berada di berbagai belahan dunia. Melalui media ini, mereka dapat memperoleh dan menyampaikan berbagai informasi yang dibutuhkan kapan saja dan dimana 
saja. Dengan jaringan yang global, internet dapat diakses 24 jam sehari 7 hari seminggu. Begitu memerlukan informasi tertentu, kita hanya perlu mengakses internet dan dalam sekejap kita dapat memperoleh informasi apapun yang kita butuhkan. Dapat dibayangkan betapa besarnya peranan media internet ini dalam kehidupan kita. Saat ini internet tidak hanya digunakan manusia dalam mencari informasi saja, mereka juga menggunakan media internet untuk melakukan bisnis dengan membangun sebuah website.

Sebelum mengenal media internet, manusia dalam mencari informasi cukup banyak memakan biaya dan waktu yang sangat lama. Terutama dalam kegiatan pengumpulan dan pencarian data yang semuanya masih mengandalkan media kertas, mereka harus mencetak ribuan brosur, pamflet, katalog, dan media lainnya. Teknik distribusi seperti ini membutuhkan biaya dan waktu yang tidak sedikit. Pengguna pun menjadi tidak leluasa dalam mendapatkan informasi produk dan layanan terbaik yang disediakan karena aktivitas mereka dalam mengakses informasi dibatasi oleh ruang dan waktu.

Kini dengan hadirnya internet, kita dapat melakukan kegiatan lebih mudah. Kita dapat menampilkan berbagai informasi dan layanan yang kita sediakan. Bahkan kita dapat meng-update informasi yang kita tampilkan kapan saja, tanpa perlu menghabiskan banyak biaya.

Kantor Kepala Desa Puput merupakan sebuah instansi pemerintah yang berfungsi untuk memberikan berbagai layanan untuk menjawab kebutuhan sarana dan prasarana telekomunikasi dan teknologi informasi dalam aktivitas pelayanan untuk masyarakat, dimana sangat ini pengolahan data kependudukannya dilakukan secara manual sehingga memperlambat kinerja pada instansi tersebut. Media penyimpanan data kependudukannya pun masih menggunakan dokumen-dokumen sehingga rentan kehilangan atau kerusakan data, sering terjadi pengulangan data kependudukan dikarenakan tidak adanya pendataan yang telah tersistem. Kurangnya pengembangan terhadap sistem informasi kependudukan guna mengelola dan menyajikan informasi serta laporan-laporan sesuai dengan kebutuhan pada Kantor Kepala Desa Puput mempunyai optimalisasi proses kerja di desa tersebut.

Untuk mengatasi kelemahan dan kekurangan tersebut, maka Kantor Desa Puput memerlukan pengembangan suatu sistem yang memberikan informasi tentang jasa, pelayanan, dan infrastruktur desa agar memudahkan para masyarkat untuk memperoleh informasi data kependudukan. Dari sistem yang akan dirancang dapat membantu kantor kepala desa dalam mengembangkan visi, misi, kepada masyarakat di wilyah tersebut. Untuk mencapai tujuan diatas, maka judul yang baik untuk penelitian ini salah satunya adalah "Penerapan Aplikasi Sistem Informasi Kependudukan Berbasis Web Pada Kantor Kepala Desa Puput Kecamatan Simpang Katis".

\section{METODOLOGI PENELITIAN}

Metode penelitian adalah menggambarkan cara mengumpulkan informasi-informasi dan data yang diperlukan sebagai bahan untuk penyusunan laporan penelitian ini, antara lain sebagai berikut :

\subsection{Metode Pengumpulan Data}

a. Penelitian Lapangan Pengumpulan data untuk keperluan riset dari Kantor Kepala Desa Puput sebagai acuan untuk merancang dan menganalisa.

b. Penelitian Kepustakaan (Studi Literatur)

Dalam hal ini pengumpulan data serta keterangan-keterangan dapat dilakukan dengan membaca serta mempelajari buku-buku ataupun literatur, serta sumber informasi lainnya yang berhubungan dengan objek yang diteliti.

c. Wawancara

Pengumpulan data dengan mewawancari bapak lurah serta sekretaris kelurahan ini digunakan untuk menyakinkan bahwa data yang diperoleh benar-benar dari sumber yang kompeten.

\subsection{Analisa Berorientasi Obyek}

Analisis berorientasi obyek atau Object-Oriented Analisis (OOA) dimulai dengan menyatakan suatu masalah, analis membuat model situasi dari dunia nyata, menggambarkan sifat yang penting. Dalam menganalisa suatu sistem, analis harus bekerja dengan pihak yang membutuhkan sistem untuk memahami masalah tersebut dengan jelas. UML ( Unfied Modelling Language) adalah salah satu alat bantu yang sangat handal di dunia pengembangan sistem yang berorientasi obyek. Hal ini disebabkan karena UML menyediakan bahasa pemodelan visual yang memungkinkan bagi pengembang sistem untuk membuat cetak biru atas visi mereka dalam bentuk yang baku, mudah dimengerti serta dilengkapi dengan mekanisme yang efektif untuk berbagi ( sharing ) dan mengkomunikasikan rancangan mereka dengan yang lain. 
Metode Booch dari Grady Booch sangat terkenal dengan nama metode Design Object Oriented. Metode ini menjadikan proses analisis dan design ke dalam empat tahapan interatif, yaitu identifikasi kelas-kelas dan obyek-obyek, identifikasi semantik dari hubungan obyek dan kelas tersebut, perincian interface dan implementasi. Keunggulan metode Booch adalah pada detil dan kayanya dengan notasi dan elemen.[1]

a. Activity Diagram

Activity diagram menggambarkan proses bisnis dan urutan aktifitas dalam sebuah proses, yang mana dipakai pada business modelling untuk memperlihatkan urutan aktifitas proses bisnis karena bermanfaat untuk membantu memahami proses secara keseluruhan dalam memodelkan sebuah proses.

b. Use Case Diagram

Use case diagram menggambarkan kebutuhan sistem dari sudut pandang user dan memfokuskan pada proses komputerisasi. Sebuah use case dapat menggambarkan hubungan antara use case dengan actor. Secara umum use case adalah pola perilaku sistem dan urutan transaksi yang berhubungan yang dilakukan oleh satu actor.

c. Class Diagram

Class adalah sebuah spesifikasi yang jika diinstansiasi akan menghasilkan sebuah obyek dan merupakan inti dari pengembangan dan desain berorientasi obyek. Class menggambarkan keadaan (atribut/properti) suatu sistem, sekaligus menawarkan layanan untuk memanipulasi keadaan tersebut (metode/fungsi). Class diagram menggambarkan struktur dan deskripsi class, package dan obyek beserta hubungan satu sama lain seperti containment, pewarisan, asosiasi, dan lain-lain. Class memiliki tiga area pokok, yaitu :

1. Nama (dan stereotype)

2. Atribut

3. Metode

\subsection{Tinjauan Pustaka}

a. Syarif Hidayatullah: Metode Penelitian yang digunakan adalah system development life cycle (SDLC). Sistem yang disusun ini dapat untuk melayani permohonan berbagai produk administrasi kependudukan secara online, maupun secara langsung, sehingga akan sangat memudahkan masyarakat. Sistem yang disusun ini juga dapat untuk memproses mutasi kependudukan (kelahiran dan kematian), serta menyimpan surat-surat yang pernah diproses kemudian ditampilkan dalam bentuk laporan yang dapat dicetak. Dengan adanya sistem ini, berbagai permasalahan dalam pelayanan administrasi kependudukan di Desa Candigatak dapat teratasi.[2]

b. Fiftin Novianto, Tedy Setiadi, dan Iis Wahyuningsih: Metode yang digunakan adalah waterfall. Pengguna sistem ini meluputi: Warga, Dukuh, Lurah dan Camat. Sistem dirancang untuk menerima masukkan data dari warga terkait administrasi surat menyurat. Selanjutnya dilakukan verifikasi data oleh Dukuh dan Lurah sedangkan Camat dapat memantau warga dan administrasinya setiap desa dalam wilayah pemerintahannya.Penelitian ini berhasil mengimplementasikan SIKADES (Sistem Informasi Kependudukan Desa) yang memanfaatkan teknologi Web Mobile, untuk kemudahan layanan. Berdasarkan pengujian sistem serta pelatihan yang dilaksanakan sistem ini telah layak dikembangkan dan memungkinkan pengembangan untuk daerah lain.[3]

c. Eka Asyifa Hayat, Eko Retnadi, dan Erwin Gunadhi: Tujuan dari laporan penelitian ini adalah untuk merancang sistem informasi kependudukan menggunakan metode unified approach serta untuk pemodelan sistemnya menggunakan UML sedangkan bahasa pemrogramannya menggunakan PHP dan untuk database menggunakan xampp. Hasil penelitian ini menunjukkan bahwa penggunaan sistem informasi kependudukan ini dapat membantu bagian pendaftaran dan pendataan penduduk dalam mengelola data kelahiran, kematian dan pindah datang dan proses pembuatan laporan-laporan mengenai jumlah penduduk perbulan yang diharapkan. [4]

d. Chindra Saputra dan Effiyaldi: Tujuan penelitian ini menganalisis dan merancang sistem administrasi kependudukan pada bagian pengelolan data penduduk, surat keterangan serta pelaporan yang databsenya terpusat. Penelitian ini menggunkan metode UML ( Unified Modeling Language ) untuk merancang sistem. Hasil dari penelitian ini menghasilkan perancangan sistem informasi administrasi yang mengolah data penduduk yang terintegrasi langsung untuk pembuatan surat-surat keterangan serta pelaporan yang tersistem. Rancangan ini dapat dikembangkan menjadi suatu aplikasi yang dapat diimplementasikan, serta diharapkan penelitian ini dapat menjadi referensi dan pembelajaran khususnya di bidang sistem informasi.[5]

e. Mardian Rahman :Tujuan penelitian ini menganalisis kebutuhan sistem dan mengubah sistem kependudukan menjadi sistem kependudukan yang digital berbasiskan web agar memudahkan 
pihak Kantor Camat Tembilahan Hulu dalam membuat laporan kependudukan dan menginformasikannya. Adapun teknik pengumpulan data dilakukan dengan cara wawancara dan observasi. Pengembangan sistem menggunakan metode System Development Life Cycle (SDLC). Analisis system menggunakan analisis PIECES (Performance, Information, Economy, Control, Effesiency, Services). Untuk mengumpulkan data penilaian tentang Sistem Informasi Kependudukan Menggunakan Ratting Scale Tujuannya untuk mengukur penilaian terhadap sistem yang telah dibuat. Berdasarkan analisis data dari hasil tes akhir dapat disimpulkan bahwa Sistem informasi kependudukan ini memudahkan pihak kantor Kecamatan Tembilahan Hulu dalam hal pengakuratan data laporan kependudukan, penyimpanan arsip laporan dan pencarian arsip data laporan kependudukan sehingga informasi yang dihasilkan efektif dan efisien.[6]

\section{HASIL DAN PEMBAHASAN}

\subsection{Analisa Proses}

Proses Bisnis yang dilakukan dalam Sistem Informasi Kependudukan pada Kantor Kepala Desa Puput Kec. Simpangkatis adalah sebagai berikut:

a. Proses Permohonan Pembuatan Kartu Keluarga (KK)

Penduduk mengajukan permohonan pembuatan kartu keluarga kepada Sekdes serta menyerahkan persyaratan berupa fotocopy KTP dan Buku nikah. Setelah itu Sekdes terima dan melakukan pengecekan kelengkapan persyaratan, jika belum lengkap maka Sekdes akan memberikan konfirmasi untuk melengkapi persyaratan tersebut, dan jika telah lengkap maka Sekdes membuat dan menyerahkan surat permohonan KK tersebut untuk ditandatangani oleh Kepala Desa. Setelah itu, surat tersebut diserahkan kembali ke Sekdes. Setelah itu Sekdes memberikan surat permohonan KK yang telah ditandatangani tersebut kepada penduduk.

b. Proses Pembuatan Surat Keterangan Kelahiran

Penduduk mengajukan permohonan pembuatan Surat Keterangan Kelahiran dan menyerahkan persyaratan seperti surat keterangan lahir dari Bidan/ Rumah Sakit, Buku nikah, Kartu keluarga orangtua, Fotocopy KTP orangtua, kepada Sekdes. Setelah itu Sekdes terima permohonan dan persyaratan lalu melakukan pengecekan kelengkapan persyaratan, jika belum lengkap maka Sekdes akan memberikan konfirmasi untuk melengkapi persyaratan tersebut, dan jika telah lengkap maka Sekdes membuat dan menyerahkan surat keterangan kelahiran tersebut untuk ditandatangani oleh Kepala Desa. Setelah itu, surat tersebut diserahkan kembali ke Sekdes. Setelah itu Sekdes memberikan surat keterangan kelahiran yang telah ditandatangani tersebut kepada penduduk.

c. Proses Pembuatan Surat Keterangan Kematian

Penduduk mengajukan permohonan pembuatan Surat Keterangan Kematian dan menyerahkan persyaratan seperti surat keterangan kematian dari Rumah Sakit, Fotocopy KTP dan KK yang meninggal (dilegalisir), kepada Sekdes. Setelah itu Sekdes terima permohonan dan persyaratan lalu melakukan pengecekan kelengkapan persyaratan, jika belum lengkap maka Sekdes akan memberikan konfirmasi untuk melengkapi persyaratan tersebut, dan jika telah lengkap maka Sekdes membuat dan menyerahkan surat keterangan kematian tersebut untuk ditandatangani oleh Kepala Desa. Setelah itu, surat tersebut diserahkan kembali ke Sekdes. Setelah itu Sekdes memberikan surat keterangan kematian yang telah ditandatangani tersebut kepada penduduk.

d. Proses Pembuatan Surat Pindah Jiwa

Penduduk mengajukan permohonan pindah jiwa dan menyerahkan persayaratan berupa fotocopy KK, dan fotocopy KTP, kepada Sekdes, kemudian Sekdes terima dan melakukan pengecekan kelengkapan persyaratan, jika belum lengkap maka Sekdes akan memberikan konfirmasi untuk melengkapi persyaratan tersebut, dan jika telah lengkap maka Sekdes membuat dan menyerahkan surat keterangan pindah jiwa tersebut untuk ditandatangani oleh Kepala Desa. Setelah itu, surat tersebut diserahkan kembali ke Sekdes. Setelah itu Sekdes memberikan surat keterangan pindah jiwa yang telah ditandatangani tersebut kepada penduduk.

\subsection{Activity Diagram}

Beberapa Activity Diagram dibawah ini menggambarkan proses bisnis sistem berjalan di Kantor Kepala Desa Puput Kec. Simpangkatis.

a. Activity Diagram Proses Permohonan Pembuataan Kartu Keluarga (KK) 


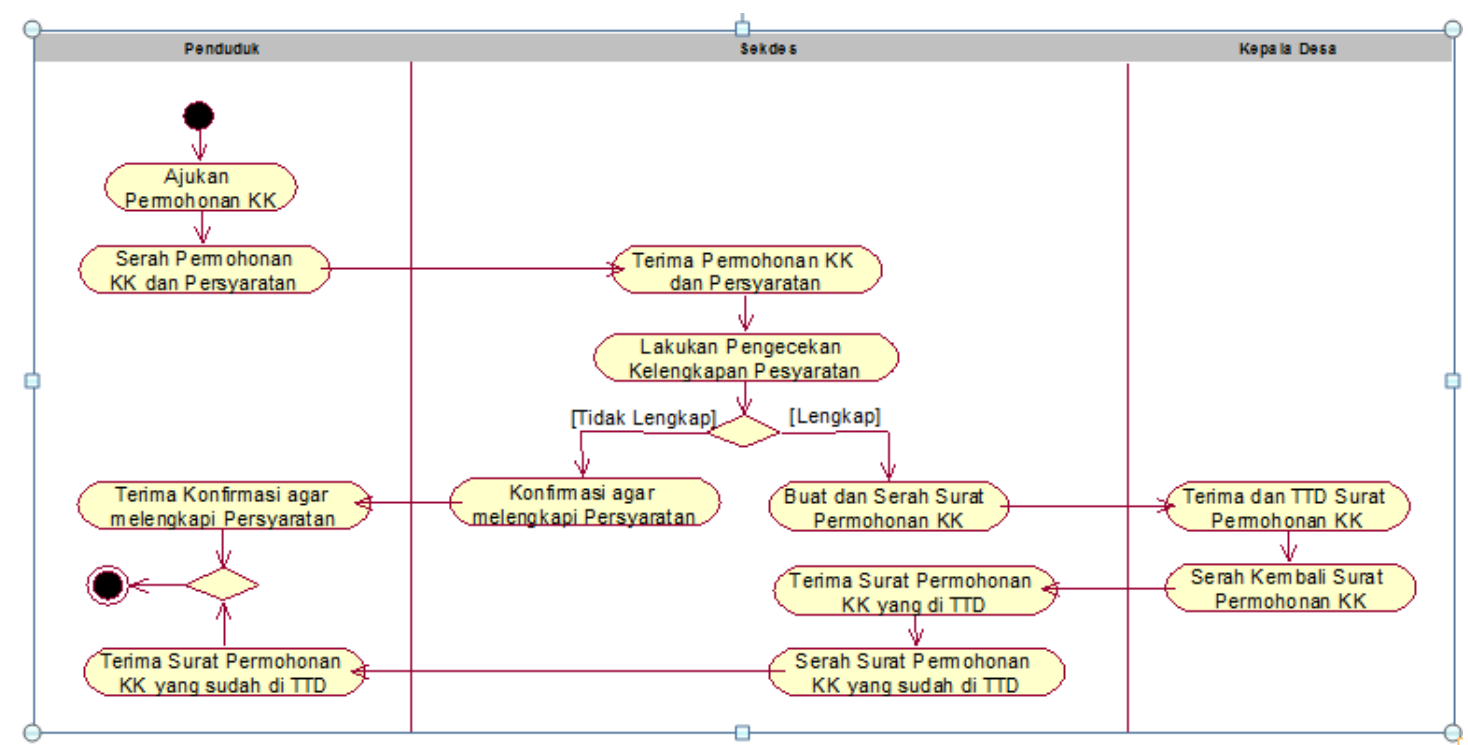

Gambar 1. Activity Diagram Proses Permohonan Pembuatan KK

b. Activity Diagram Proses Pembuatan Surat Keterangan Kelahiran

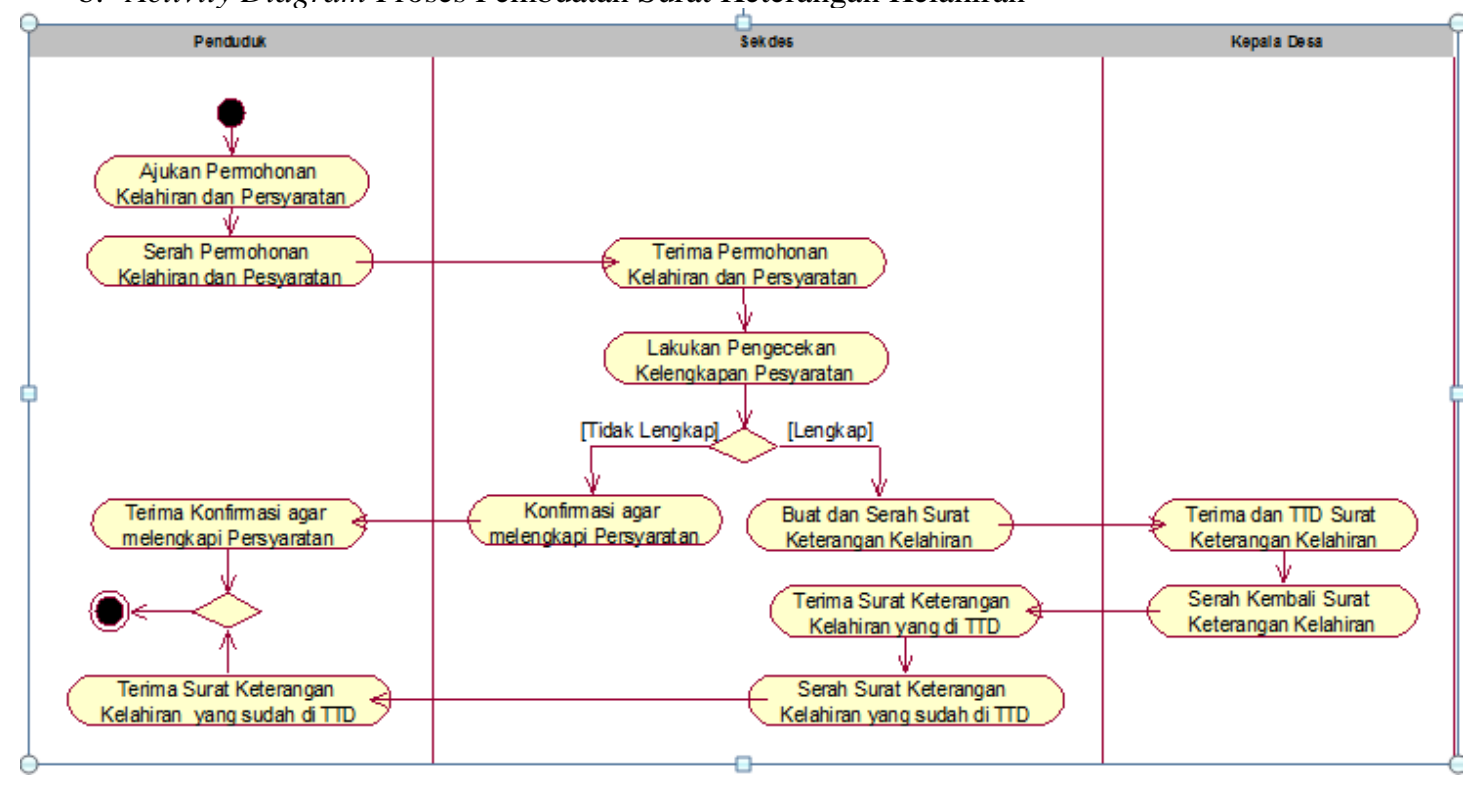

Gambar 2. Activity Diagram Proses Pembuatan Surat Keterangan Kelahiran

\subsection{Use Case Diagram}

Use Case Diagram digunakan untuk menjelaskan manfaat sistem yang dilihat dari sudut pandang user. Adapun Usecase diagram yan dihasilkan sistem usulan ini adalah : 


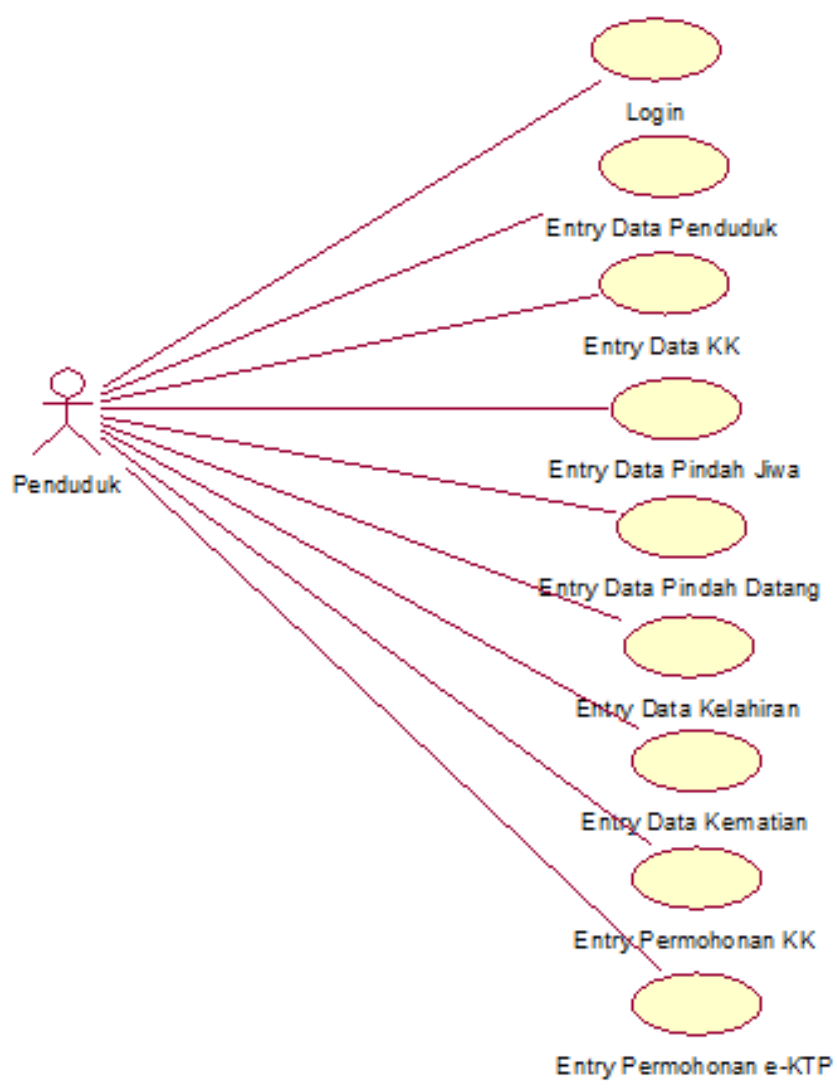

Gambar 3. UseCase Diagram Sistem Usulan

\subsection{Entity Relationship Diagram}

Rancangan basis data untuk penyimpanan data digambarkan dalam bentuk model ERD. Berikut adalah rancangan diagram ER hasil analisa dari pengumpulan data:

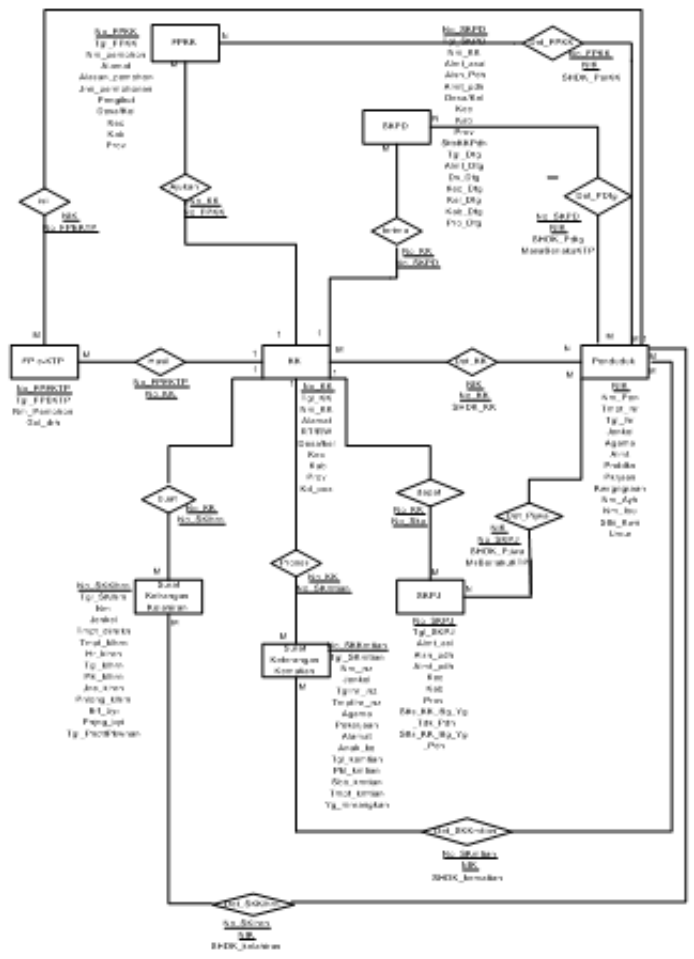

Gambar 4. Entity Relationship Diagram 


\subsection{Rancangan Layar}

\subsubsection{Rancangan Layar Entri Data Penduduk}

Menggambarkan bentuk tampilan layar untuk memasukan data penduduk sebagai data master didalam sistem informasi kependudukan.

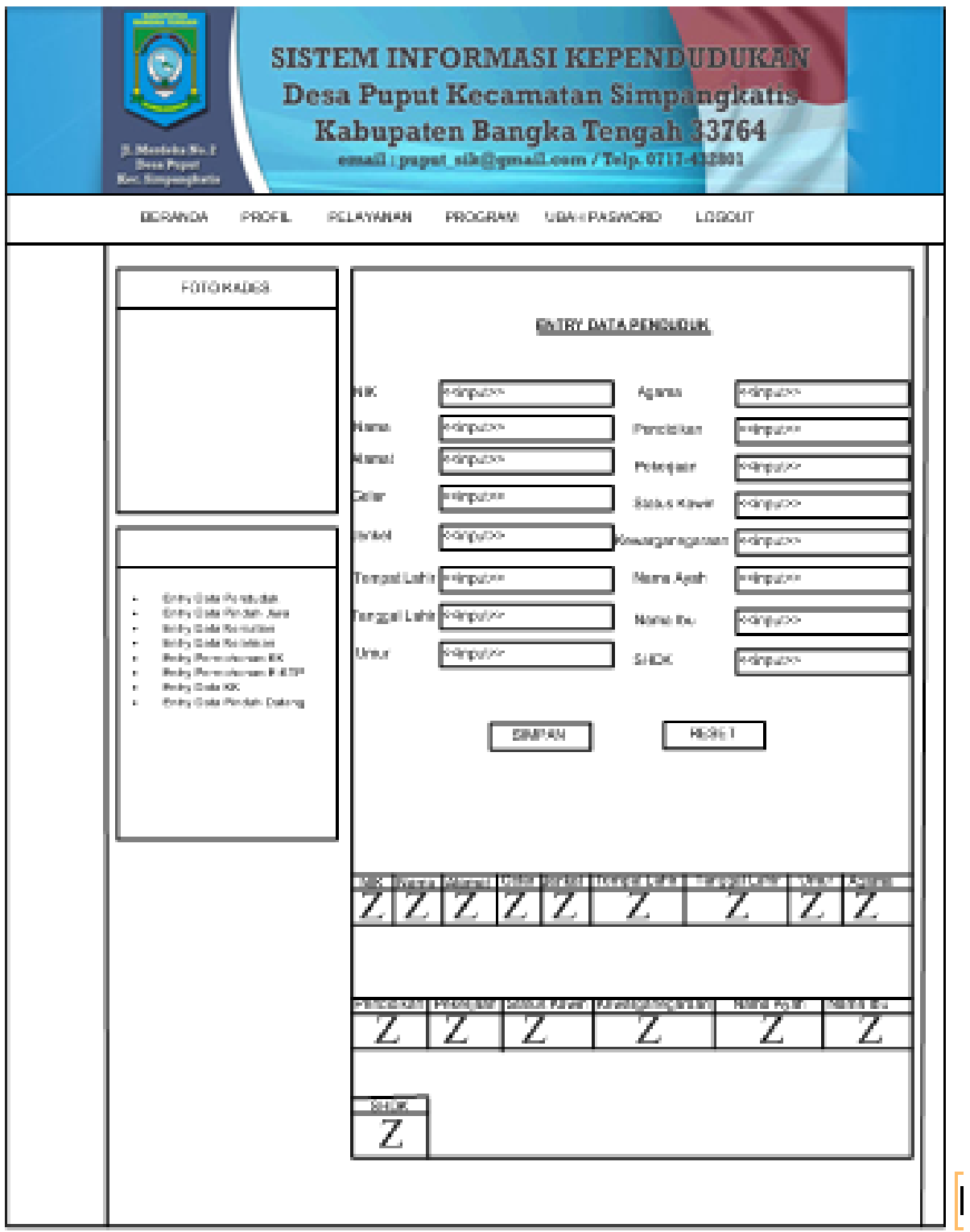

Gambar 5. Rancangan Layar Entri Data Penduduk

\subsubsection{Rancangan Layar Entri Data Pindah Jiwa}

Menggambarkan bentuk tampilan layar untuk memasukan data penduduk yang akan pindah jiwa. 


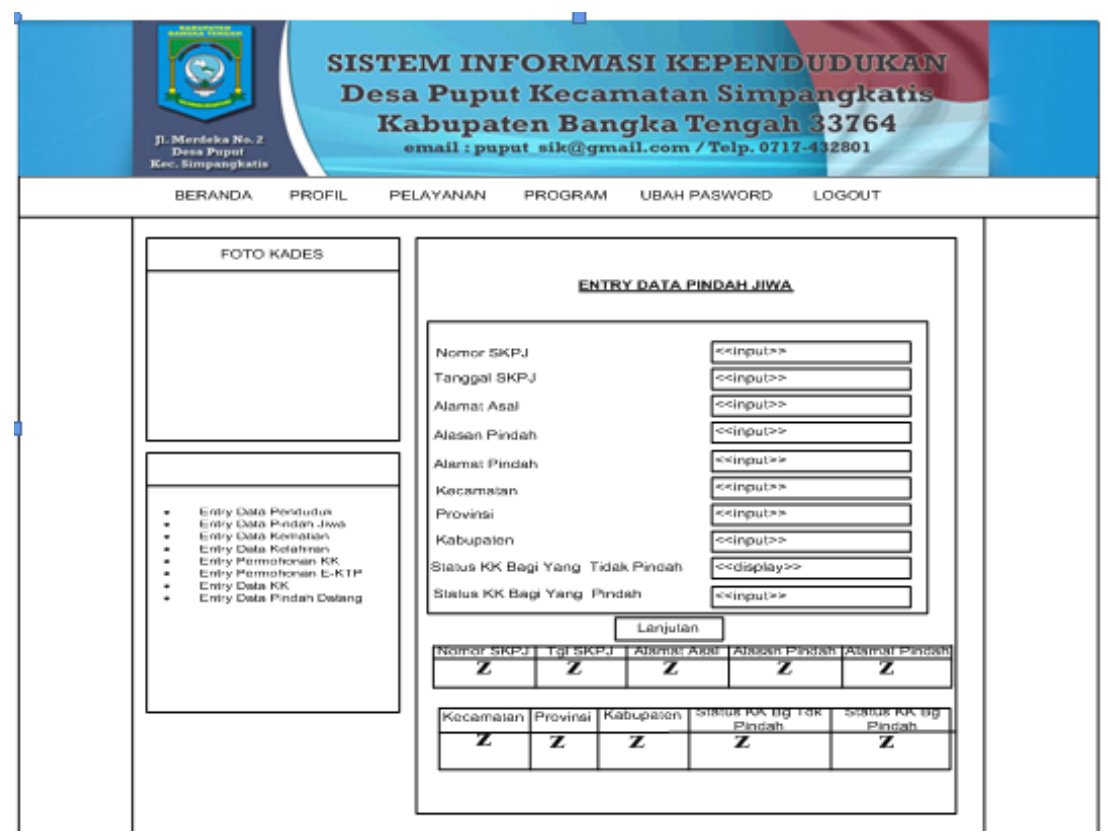

Gambar 6. Rancangan Layar Entry Data Pindah Jiwa

\subsubsection{Rancangan Layar Entry Data Kelahiran}

Menggambarkan bentuk tampilan layar untuk memasukan data kelahiran, jika ada penduduk yang melahirkan data kelahirannya akan dientri layar ini.

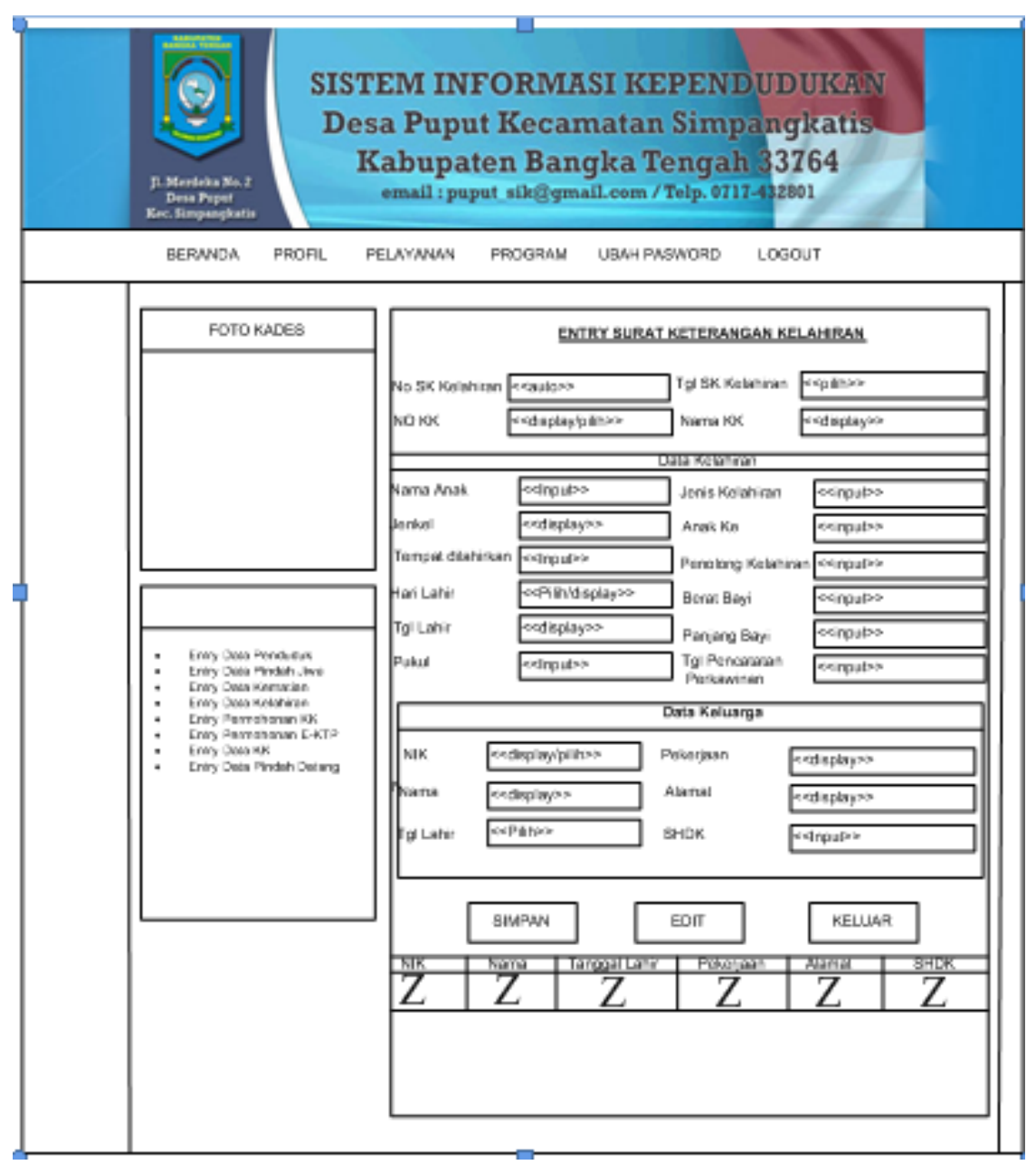

Gambar 7. Rancangan Layar Entry Data Kelahiran 


\subsubsection{Rancangan Layar Entry Data Kematian}

Menggambarkan bentuk tampilan layar untuk memasukan data kematian, jika ada penduduk yang meninggal maka data kematiannya akan dientri layar ini.

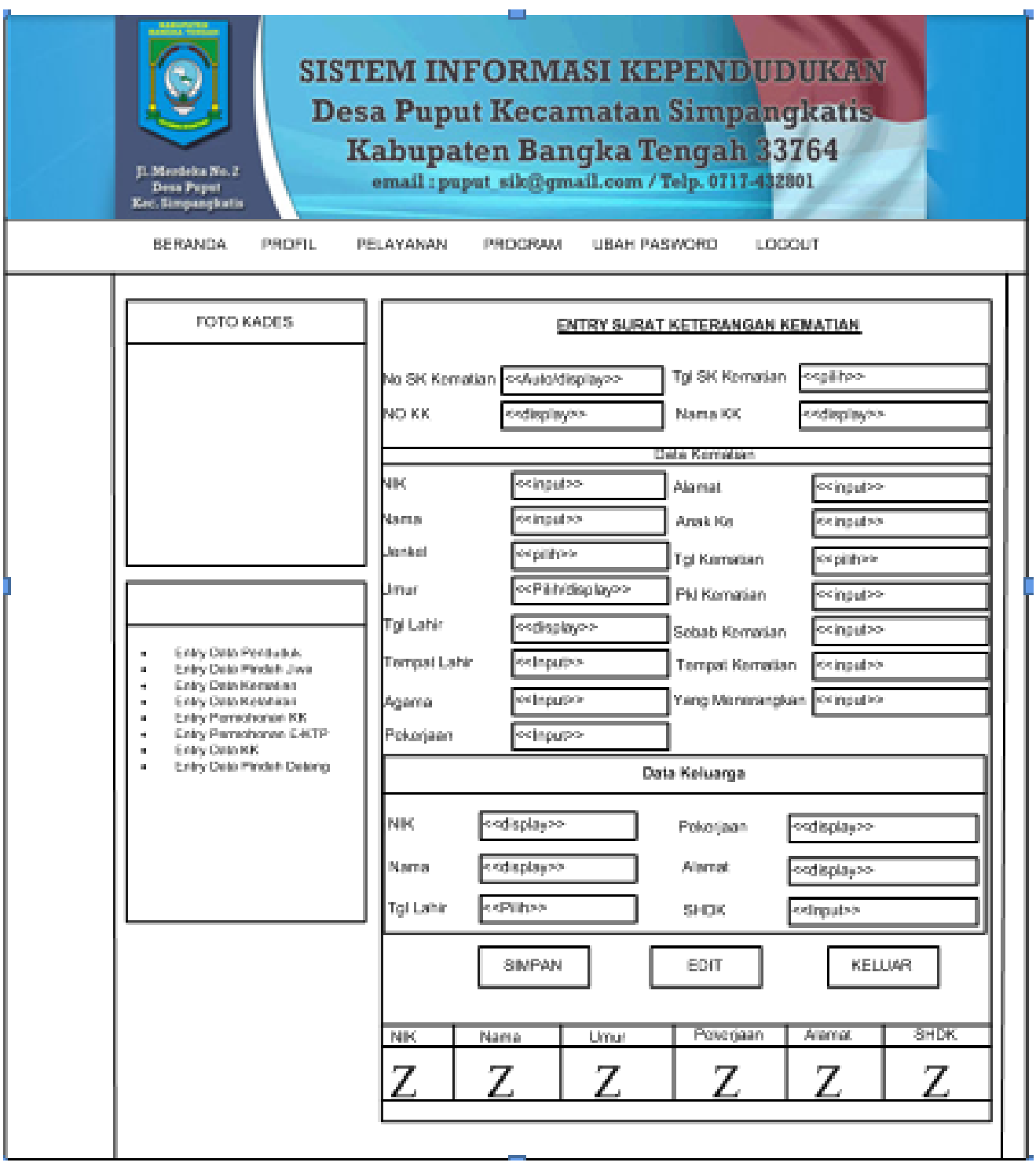

Gambar 8. Rancangan Layar Entry Data Kematian

\section{KESIMPULAN}

Aplikasi berbasis web yang dihasilkan dari analisa dan perancangan ini dapat mengatasi masalah yang ada di Kantor Kepala Desa Puput Kecamatan Simpangkatis yaitu:

a. Proses pengolahan data dapat lebih cepat dan meminimalisasikan kerangkapan data.

b. Dapat meningkatkan efektifitas dan efisiensi dalam pelayanan terhadap masyarakat yang lebih baik sehingga dapat memajukan kinerja di Kantor Kepala Desa Puput Kecamatan Simpangkatis.

c. Dapat menjadi sebuah sistem pelayanan kependudukan yang dapat meningkatkan pelayanan terhadap masyarakat.

d. Dapat menyajikan informasi serta laporan-laporan sesuai kebutuhan dengan lebih akurat dan cepat sehingga mendukung dalam pengambilan keputusan oleh pegawai pemerintah desa.

Untuk menunjang sistem informasi kependudukan berbasis web ini, perlunya sumber daya manusia yang dan pelatihan mengenai cara penggunaan sistem selain itu perlu adanya jaringan internet untuk mengakses web. Untuk system perlu keamanan data yang terjamin sehingga data yang dihasilkan dapat dipertanggungjawabkan dan perlu dilakukan backup data secara berkala untuk mencegah terjadinya kerusakan data. 


\section{DAFTAR PUSTAKA}

[1] Nugroho, Adi.(2007). Analisis \& Perancangan Sistem Informasi Dengan Metodelogi Berorientasi Objek Ed.Revisi, Informatika

[2] Syarif, H, dan Cisde, M, 2015. "Sistem Pelayanan Administrasi Kependudukan Desa Candigatak Berbasis Web”. Jurnal IT CIDA, Vol.1, No.1, Desember 2015. ISSN : 2477-8133

[3] Fiftin, N, Tedy, S, dan Iis, W, 2014 "Implementasi SIKADES (Sistem Informasi Kependudukan Desa) Untuk Kemudahan Layanan Administrasi Desa Berbasis Web Mobile”. Jurnal Informatika, Vol.8, No.1, 2014. ISSN print : 2528-6374

[4] Eka, AH, Eko, R, dan Erwin, G, 2014. "Perancangan Sistem Informasi Kependudukan Berbasis Web". Jurnal Algoritma STT Garut, Vol.11, No.1, ISSN : 2302-7339

[5] Chindra, S, dan Effiyaldi, 2017. "Analisa dan Perancangan Sistem Informasi Administrasi Kependudukan Pada Desa Kota Karang”. Jurnal Manajemen Sistem Informasi, Vol.2, No.3, September 2017.

[6] Mardian, R, 2016. "Analisa dan Perancangan Sistem Informasi Kependudukan di Kecamatan Tembilahan Hulu Berbasis Web”. Jurnal BAPEDA, Vol.2, No.2, Agustus 2016, ISSN : 2442-7845. 